\title{
Carbon dioxide exchange of a perennial bioenergy crop cultivation on a mineral soil
}

\author{
Saara E. Lind ${ }^{1}$, Narasinha J. Shurpali ${ }^{1}$, Olli Peltola ${ }^{2}$, Ivan Mammarella ${ }^{2}$, Niina Hyvönen ${ }^{1}$, Marja Maljanen ${ }^{1}$, \\ Mari Räty $^{3}$, Perttu Virkajärvi ${ }^{3}$, and Pertti J. Martikainen ${ }^{1}$ \\ ${ }^{1}$ Department of Environmental Science, University of Eastern Finland, Yliopistonranta 1 E, P.O. Box 1627, Kuopio Campus, \\ 70211, Finland \\ ${ }^{2}$ Department of Physics, P.O. Box 48, 00014 University of Helsinki, Helsinki, Finland \\ ${ }^{3}$ Natural Resources Institute Finland, Green Technology, Halolantie 31 A, 71750 Maaninka, Finland
}

Correspondence to: Saara E. Lind (saara.lind@uef.fi)

Received: 4 September 2015 - Published in Biogeosciences Discuss.: 19 October 2015

Revised: 11 February 2016 - Accepted: 13 February 2016 - Published: 1 March 2016

\begin{abstract}
One of the strategies to reduce carbon dioxide $\left(\mathrm{CO}_{2}\right)$ emissions from the energy sector is to increase the use of renewable energy sources such as bioenergy crops. Bioenergy is not necessarily carbon neutral because of greenhouse gas (GHG) emissions during biomass production, field management and transportation. The present study focuses on the cultivation of reed canary grass (RCG, Phalaris arundinacea L.), a perennial bioenergy crop, on a mineral soil. To quantify the $\mathrm{CO}_{2}$ exchange of this RCG cultivation system, and to understand the key factors controlling its $\mathrm{CO}_{2}$ exchange, the net ecosystem $\mathrm{CO}_{2}$ exchange (NEE) was measured from July 2009 until the end of 2011 using the eddy covariance (EC) method. The RCG cultivation thrived well producing yields of 6200 and $6700 \mathrm{~kg} \mathrm{DW} \mathrm{ha}^{-1}$ in 2010 and 2011, respectively. Gross photosynthesis (GPP) was controlled mainly by radiation from June to September. Vapour pressure deficit (VPD), air temperature or soil moisture did not limit photosynthesis during the growing season. Total ecosystem respiration (TER) increased with soil temperature, green area index and GPP. Annual NEE was -262 and $-256 \mathrm{~g} \mathrm{C} \mathrm{m}^{-2}$ in 2010 and 2011, respectively. Throughout the study period from July 2009 until the end of 2011, cumulative NEE was $-575 \mathrm{~g} \mathrm{C} \mathrm{m}^{-2}$. Carbon balance and its regulatory factors were compared to the published results of a comparison site on drained organic soil cultivated with RCG in the same climate. On this mineral soil site, the RCG had higher capacity to take up $\mathrm{CO}_{2}$ from the atmosphere than on the comparison site.
\end{abstract}

\section{Introduction}

Anthropogenic increase in the atmospheric concentration of greenhouse gases (GHGs) has been considered the major reason for the global climate warming (IPCC, 2013). The carbon dioxide $\left(\mathrm{CO}_{2}\right)$ concentration in the atmosphere has increased from 278 to $391 \mathrm{ppm}$ between 1750 and 2011 and is still increasing (IPCC, 2013). Carbon dioxide emitted to the atmosphere originates mainly from respiration (plants and microorganisms) and fossil fuel combustion with the main sinks being photosynthesis and oceans (IPCC, 2013). In Finland the energy sector and agriculture are the most important in the total national GHG emissions (Statistics Finland, 2014).

One of the strategies to reduce $\mathrm{CO}_{2}$ emissions from the energy sector is to increase the use of renewable energy sources, e.g. using biomass. Bioenergy produced from biomass is not necessarily carbon neutral because of GHG emissions during biomass production, field management and transportation. Life-cycle assessment (LCA) results have been recently reported for reed canary grass (RCG, Phalaris arundinacea L.) cultivation on cut-away peatlands in Finland (Shurpali et al., 2010) and Estonia (Järveoja et al., 2013). In these studies, the RCG sites were net sinks for $\mathrm{CO}_{2}$ and hence, RCG is suggested to be a good after-use option for such marginal soils which are known to release large amount of $\mathrm{CO}_{2}$ as a result of decomposition of residual peat, when left abandoned (Kasimir-Klemedtsson et al., 1997).

Cultivation of RCG has been popular in Finland since the mid-1990s and at the peak approximately 19000 ha (2007 and 2008) were cultivated with RCG. However, owing to 
technical difficulties with the burning of the RCG biomass in combustion plants, the scope of RCG as a source of biomass bioenergy has declined in the last few years. In 2014, the average cultivation area was around 6000 ha. Nevertheless, the scope for RCG as a source of liquid biofuel, a digestate in biogas plants, oil spill absorption and a buffer crop between terrestrial and aquatic landscape is wide (Pasila and Kymäläinen, 2000; Partala et al., 2001; Powlson et al., 2005; Kandel et al., 2013b).

RCG is a perennial crop which is well adapted to the northern climatic conditions. It has a rotation time of up to 15 years. The annually harvested yield up to $12000 \mathrm{~kg} \mathrm{DW} \mathrm{ha}^{-1}$ has been reported (Lewandowski et al., 2003). As a perennial crop, it has advantages over the annual cropping systems. The crop growth following the first overwintering starts earlier as the re-establishment of the crop in the spring is not needed. This cultivation style also reduces the use of machinery at the site since e.g. annual tilling is not required.

While continuous and long-term measurements of GHG balance from bioenergy crops are needed to evaluate the atmospheric impact of the whole production chain, to our knowledge, there are no GHG flux measurements from RCG cultivation on mineral soils. With this in view, we measured the $\mathrm{CO}_{2}$ balance of RCG crop cultivation (2009-2011) on a mineral soil by the eddy covariance (EC) technique. Our objectives in this paper are to quantify and characterize the net ecosystem exchange (NEE) of a perennial crop cultivated on a mineral soil and to investigate the factors controlling its $\mathrm{CO}_{2}$ balance. Additionally, we aim to compare our findings from the mineral soil site to the published data on of a RCG cultivation system on a drained organic soil (referred to hereafter as comparison site) in the same climate region.

\section{Materials and methods}

\subsection{Study site and agricultural practices}

The study site is located in Maaninka $\left(63^{\circ} 09^{\prime} 49^{\prime \prime} \mathrm{N}\right.$, $27^{\circ} 14^{\prime} 3^{\prime \prime} \mathrm{E}, 89 \mathrm{~m}$ above the mean sea level) in eastern Finland. Long-term (30 years, reference period 1981-2010; Pirinen et al., 2012) annual air temperature in the region is $3.2^{\circ} \mathrm{C}$ with February being the coldest $\left(-9.4^{\circ} \mathrm{C}\right)$ and July the warmest $\left(17.0^{\circ} \mathrm{C}\right)$ month. The annual precipitation in the region is $612 \mathrm{~mm}$ with a seasonal amount of $322 \mathrm{~mm}$ during the May-September period.

The experimental site is a 6.3 ha $(280 \times 220 \mathrm{~m})$ agricultural field cultivated with RCG (cv. "Palaton"). During the last 10 years prior to planting of RCG, the field was cultivated with grass (Phleum pratense L.; Festuca pratensis Huds.), barley (Hordeum vulgare L.) or oat (Avena sativa L.). For a detailed soil analysis three $100 \mathrm{~cm}$ deep soil pits were excavated and eight $6 \mathrm{~cm}$ deep horizons between 0 and $93 \mathrm{~cm}$ were sampled in July 2010. Three undisturbed soil samples from each horizon were taken with steel cylinders (height $6.0 \mathrm{~cm}$, diameter $5.7 \mathrm{~cm}$ ). Two soil samples were used for determination of soil physical properties and one for the chemical properties. To characterize properties of top soil $(0-18 \mathrm{~cm})$ in general, soil samples taken at depths of $0-6$, $6-12,12-18 \mathrm{~cm}$ were analysed separately, and mean values over the horizons were calculated for each pit. The results shown here are means ( \pm standard deviation) over the three pits. The soil samples were oven dried at $35^{\circ} \mathrm{C}$ and ground to pass through a $2 \mathrm{~mm}$ sieve. The particle-size distribution was determined with the pipette method (Elonen, 1971). Total organic $\mathrm{C}$ and total $\mathrm{N}$ contents were determined by dry combustion using a Leco ${ }^{\circledR}$ analyser, the soil particle density with a stoppered bottle pycnometer method and bulk density was calculated as a ratio of the dry weight (oven dried at $105^{\circ} \mathrm{C}$ ) and sampling volume of the soil. Soil $\mathrm{pH}$ and electrical conductivity were measured in soil-water suspension $(1: 2.5 v / v)$. The easily soluble $\mathrm{P}$ and exchangeable $\mathrm{K}$ were extracted with acid ammonium acetate at $\mathrm{pH} 4.7$, as described by Vuorinen and Mäkitie (1955).

The soil was classified as a Haplic Cambisol/Regosol (Hypereutric, Siltic) (IUSS Working Group WRB, 2007), the topsoil being generally silt loam (clay mean $25 \pm 5.6 \%$, silt $53 \pm 9.0 \%$ and sand $22 \pm 7.8 \%$ ) based on the US Department of Agriculture (USDA) textural classification system. The average soil characteristics in the topsoil were as follows: $\mathrm{pH}\left(\mathrm{H}_{2} \mathrm{O}\right) 5.8 \pm 0.19$, electrical conductivity $14 \pm 2.4 \mathrm{mS} \mathrm{m}^{-1}$, soil organic matter $5.2 \pm 0.90 \%$, organic carbon $3.0 \pm 0.52 \%$, total nitrogen $0.2 \pm 0.03 \%$, $\mathrm{C}: \mathrm{N}$ ratio $15 \pm 0.4$, the acid ammonium acetate extractable K $104 \pm 12.9 \mathrm{mg} \mathrm{L}^{-1}$ soil, P $5.4 \pm 1.28 \mathrm{mg} \mathrm{L}^{-1}$ soil, particle density $2.65 \pm 0.014 \mathrm{~g} \mathrm{~cm}^{-3}$ and bulk density $1.1 \pm 0.11 \mathrm{~g} \mathrm{~cm}^{-3}$. Based on the soil moisture retention curve, the field capacity was $39.7 \pm 1.2 \%$ (soil moisture $(v / v))$ and wilting point was $21.6 \pm 0.8 \%$ (soil moisture $(v / v))$.

In the beginning of June 2009, the sowing of RCG was done with a seed rate of $10.5 \mathrm{~kg} \mathrm{ha}^{-1}$ together with the application of a mineral fertilizer $\left(60 \mathrm{~kg} \mathrm{Nha}^{-1}, 30 \mathrm{~kg} \mathrm{Pha}^{-1}\right.$ and $45 \mathrm{~kg} \mathrm{~K} \mathrm{ha}^{-1}$ ). The field was rolled prior to and after sowing. Additional sowing was done to fill the seedling gaps in June and July. Herbicide (mixture of MPCA $200 \mathrm{~g} \mathrm{~L}^{-1}$, clopyralid $20 \mathrm{~g} \mathrm{~L}^{-1}$ and fluroxypyr $40 \mathrm{~g} \mathrm{~L}^{-1}, 2 \mathrm{~L}$ in $200 \mathrm{~L}$ of water $\mathrm{ha}^{-1}$ ) was applied by the end of July 2009 to control the weeds. Mineral fertilizer was applied as surface application in spring $2010\left(70 \mathrm{~kg} \mathrm{~N} \mathrm{ha}^{-1}, 11 \mathrm{~kg} \mathrm{Pha}^{-1}\right.$ and $\left.18 \mathrm{~kg} \mathrm{Kha}^{-1}\right)$ and spring $2011\left(76 \mathrm{~kg} \mathrm{Nha}^{-1}, 11 \mathrm{~kg} \mathrm{Pha}^{-1}\right.$ and $19 \mathrm{~kg} \mathrm{Kha}^{-1}$ ). The biomass produced during the first growing season was not harvested but left on the site. During the following years, the harvesting was done in the spring after the growing season (28 April 2011 and 9 May 2012). Thus, the spring 2011 was the first time when the crop was harvested after its establishment in the summer of 2009. As produced biomass was used for burning, keeping the crop at the site over winter is a standard RCG cultivation practise in the Nordic countries, as spring harvesting has been shown 
to improve the quality of the biomass for burning (Burvall, 1997). The biomass was harvested using farm-scale machinery. The naturally dried vegetation was cut with a conventional disc mower (without conditioner) to approx. $5 \mathrm{~cm}$ stubble height, swathed and baled into round bales 1-2 days after cutting.

\subsection{Micrometeorological measurements}

Measurements of $\mathrm{CO}_{2}$, latent heat (LE) and sensible heat $(H)$ fluxes were carried out from July 2009 until the end of 2011 using the closed-path EC method (Baldocchi, 2003). A measurement mast was installed approximately in the middle of the field and the instrument cabin was located about $10 \mathrm{~m}$ east of the EC mast. The prevailing wind direction was northerly with a $24 \%$ occurrence during the study period. The EC instrumentation consisted of an infra-red gas analyser (IRGA) for $\mathrm{CO}_{2}$ and water vapour $\left(\mathrm{H}_{2} \mathrm{O}\right)$ concentrations (model: Li-7000 (primary) or Li-6262 (backup), LiCor) and a sonic anemometer (model: R3-50, Gill Instruments Ltd, UK) for wind velocity components and sonic temperature. The mast height was $2,2.4$ or $2.5 \mathrm{~m}$, adjusted according to the vegetation height. Except for the wind sector from 85 to $130^{\circ}$ downwind of the instrument cabin, all wind directions were acceptable because no other obstacles were present and the sonic anemometer in use had an omnidirectional geometry.

A heated gas sampling line (inner diameter $4 \mathrm{~mm}$, length $8 \mathrm{~m}$ polytetrafluoroethylene (PTFE) $+0.5 \mathrm{~m}$ metal) with two filters (pore size $1.0 \mu \mathrm{m}$, PTFE, Gelman ${ }^{\circledR}$ or Millipore ${ }^{\circledR}$ ) was used to draw air with a flow rate of initially $6 \mathrm{~L} \mathrm{~min}^{-1}$ (until 31 March 2011). Subsequently, a flow rate of $9 \mathrm{~L} \mathrm{~min}^{-1}$ was used. The IRGA was housed in a climate-controlled cabin. Reference gas flow, created using soda lime and anhydrone, also fitted with a Gelman ${ }^{\circledR}$ filter, was $0.3 \mathrm{~L} \mathrm{~min}^{-1}$. The IRGA was calibrated approximately every second week with a twopoint calibration ( 0 and $399 \mu \mathrm{LL}^{-1}$ of $\mathrm{CO}_{2}$, AGA Oy, Finland) and additionally with a dew point generator (model: LI-610, LiCor) for $\mathrm{H}_{2} \mathrm{O}$ mixing ratio during conditions when air temperature was above $+5^{\circ} \mathrm{C}$.

Data collection was done at $10 \mathrm{~Hz}$ using the Edisol program (Moncrieff et al., 1997). The 30 min EC flux values were calculated from the covariance of the scalars and vertical wind velocity (e.g. Aubinet et al., 2000). Data processing was done using EddyUH post-processing software (Mammarella et al., 2016). Despiking was done by defining a limit for the difference in subsequent data points for $\mathrm{CO}_{2}$ $\left(15 \mu \mathrm{LL}^{-1}\right)$ and $\mathrm{H}_{2} \mathrm{O}\left(20 \mathrm{mmol} \mathrm{mol}^{-1}\right)$ concentrations, wind components $\left(u=10 \mathrm{~m} \mathrm{~s}^{-1}, v=10 \mathrm{~m} \mathrm{~s}^{-1}\right.$ and $\left.w=5 \mathrm{~m} \mathrm{~s}^{-1}\right)$ and temperature $\left(5^{\circ} \mathrm{C}\right)$. A data point defined as a spike was replaced with the previous value. Point-by-point dilution correction was applied after the despiking. Two-dimensional coordinate rotation (mean lateral and vertical wind equal to zero) was done on the sonic anemometer wind components. Angle of attack correction was not applied. Detrend- ing was done using block-averaging. Lag time due to the gas sampling line was calculated by maximizing the covariance. Low-frequency spectral corrections were implemented according to Rannik and Vesala (1999). For high-frequency spectral corrections, empirical transfer function calculations were done based on the procedure introduced by Aubinet et al. (2000). Humidity effects on sonic heat fluxes were corrected according to Schotanus et al. (1983). From the processed data, flux values measured when winds were from behind the instrument cabin and those during rain events were removed. The available flux data were further quality controlled using filters as follows. We plotted the nighttime NEE with $u^{*}$ and found no correlation between the two. Nevertheless, a default $u^{*}$ filter of $0.1 \mathrm{~m} \mathrm{~s}^{-1}$ was used. Flux was considered non-stationary following Foken and Wichura (1996). In this paper, we used a limit of 0.4 (e.g. $40 \%$ difference between the sub-periods and the total averaging period). Both skewness and kurtosis of the data were checked and the acceptable skewness range was set from -3 to 3 and kurtosis from 1 to 14 . Overall flags (according to Foken et al., 2004) higher than 7 were removed. Finally, the data were visually inspected. From the available data, approximately $30 \%$ of the $\mathrm{CO}_{2}$ and $\mathrm{H}$ flux data and $40 \%$ of the LE flux data were rejected. The random errors of $30 \mathrm{~min}$ averaged and quality-controlled $\mathrm{CO}_{2}$ fluxes were determined following Vickers and Mahrt (1997). The random error was 13,12 and $14 \%$ during July-September 2009, May-September 2010 and May-September 2011, respectively. Footprints were calculated for each $30 \mathrm{~min}$ averaging period with the analytical footprint model developed by Kormann and Meixner (2001). The model is valid within the surface layer and it utilizes power law profiles for solving the footprint sizes analytically in a wide range of atmospheric stabilities. Based on the analysis, $80 \%$ of the flux was found to originate from within $130 \mathrm{~m}$ radius of the mast.

The data gap filling and flux partitioning was done using the online tool (http://www.bgc-jena.mpg.de/ MDIwork/ eddyproc/index.php). This gap-filling method considers both the co-variation of the fluxes with global radiation, temperature and vapour pressure deficit (VPD) and temporal autocorrelation of the fluxes (Reichstein et al., 2005). Flux partitioning was done excluding gap-filled data. Total ecosystem respiration (TER) was defined as the night-time measured net ecosystem $\mathrm{CO}_{2}$ exchange (NEE). The regression between night-time NEE and air temperature $(T)$ was calculated using an exponential regression model (Lloyd and Taylor, 1994) of the form

$R(T)=R_{\mathrm{ref}} e^{E_{0}\left(\frac{1}{T_{\mathrm{ref}}-T_{0}}-\frac{1}{T-T_{0}}\right)}$

where $T_{0}=-46.021{ }^{\circ} \mathrm{C}, T_{\text {ref }}=10^{\circ} \mathrm{C}$ and fitted parameters were $R_{\text {ref }}$ (the temperature independent respiration rate) and $E_{0}$ (temperature sensitivity). Using the model outputs for $R_{\text {ref }}$ and $E_{0}$, the half-hour TER was estimated using the measured air temperature. Finally, gross photosynthesis (GPP) 
was calculated as a difference between NEE and TER. In this paper, $\mathrm{CO}_{2}$ released to the atmosphere is defined as a positive value and uptake from the atmosphere as negative.

As a final step, the EC measurements were validated using the energy balance closure (EBC) determined as the slope of the regression between net radiation $\left(R_{\mathrm{n}}\right)$ and latent heat (LE), sensible heat $(H)$ and the ground heat flux $(G)$. The EBC is expressed in the following formulation (Arya, 1988) and it is a simplified formula which is valid for ideal surfaces, i.e. with no mass and heat capacity:

$R_{\mathrm{n}}=\mathrm{LE}+H+G$

The EBC was determined using data from only those $30 \mathrm{~min}$ time periods when all of the energy components were available. The slope of the regression was 0.70 in May-September 2010 and 2011. Incomplete closure is a common problem due to e.g. large eddies (Foken, 2008), angle of attack issues (Nakai et al., 2006) and also because part of the available energy is also stored in different parts of the ecosystem (Foken, 2008). Therefore, EBC was calculated so that it includes different storage terms, i.e. heat in the soil, crop canopy, amount of energy used in photosynthesis, sensible and latent heat below the EC mast (following Meyers and Hollinger, 2004 and Lindroth et al., 2010) to give a more precise estimation of the EBC. With this approach, the slope increased to 0.75. The obtained EBC is well within the range of EBCs reported for several FLUXNET sites by Wilson et al. (2002). Mauder et al. (2013) suggested that the EBC could be used as a metric for systematic uncertainty in EC fluxes. Based on this approach the systematic uncertainties of the EC fluxes reported in this study were similar to those published in other studies.

\subsection{Supporting measurements}

A weather station was set up close to the EC mast. Height of the weather station mast was adjusted according to the EC mast height. Supporting climatic variables, i.e. net radiation (model: CNR1, Kipp\&Zonen B.V.), air temperature and relative humidity (model: HMP45C, Vaisala Inc), photosynthetically active radiation (PAR, model: SKP215, Skye instruments Ltd.), amount of rainfall at $1 \mathrm{~m}$ height (model: 52203, R.M. Young Company), soil temperature at 5,10 and $30 \mathrm{~cm}$ depths (model: 107, Campbell Scientific Inc.), soil moisture at depths of 5, 10 and $30 \mathrm{~cm}$ (model: CS616, Campbell Scientific Inc.), soil heat flux at $7.5 \mathrm{~cm}$ depth (model: HPF01SC, Hukseflux) and air pressure (model: CS106 Vaisala PTB110 Barometer) were measured. Data were collected using a datalogger (model: CR 3000, Campbell Scientific Inc.). All meteorological data were collected as $30 \mathrm{~min}$ mean values (precipitation as $30 \mathrm{~min}$ sum), except air pressure which was recorded as an hourly mean. Supporting data collection began on 14 August 2009. Short gaps in the data were filled using linear interpolation. If air temperature, relative humidity, pressure or rainfall data were missing for long periods, data from Maaninka weather station, located about $6 \mathrm{~km}$ to the southeast of the site and operated by the Finnish Meteorological Institute (FMI), were used.

The RCG green area index (GA) was estimated following Wilson et al. (2007). Measurements were done approximately on a weekly basis during the main growing period and less frequently in the autumn. Three locations $\left(1 \times 1 \mathrm{~m}^{2}\right)$ were selected and within those, three spots $\left(8 \times 8 \mathrm{~cm}^{2}\right)$ were used to count the number of green stems $\left(S_{\mathrm{n}}\right)$ and leaves $\left(L_{\mathrm{n}}\right)$ per unit area. Three plants adjacent to small spots were selected for measurements of green area of leaves $\left(L_{\mathrm{a}}\right)$ and stems $\left(S_{\mathrm{a}}\right)$. Following equation was used to calculate GA $\left(\mathrm{m}^{2} \mathrm{~m}^{-2}\right)$ :

$\mathrm{GA}=\left(S_{\mathrm{n}} \cdot S_{\mathrm{a}}\right)+\left(L_{\mathrm{n}} \cdot L_{\mathrm{a}}\right)$.

Leaf area index (LAI) was measured using a plant canopy analyser (model: LAI-2000, LiCor) with a $180^{\circ}$ view cap. The LAI was measured close to GA plots at the same interval and at the same day as GA was estimated. A measurement was accepted when the standard error of LAI was less than 0.3 and the number of above and below vegetation observation pairs was more than 3 .

Above-ground biomass samples were collected approximately on a monthly basis from three locations in the field during the snow-free season in 2009, 2010 and 2011 (and root samples in 2009 and 2010). Above-ground biomass was collected from a $20 \times 20 \mathrm{~cm}^{2}$ area. Samples were dried in the oven until $\left(+65^{\circ} \mathrm{C}\right)$ the weight of the samples remained unchanged (approximately $24 \mathrm{~h}$ ) and dry weight (DW) was measured. Root biomass $(0-25 \mathrm{~cm})$ was sampled from the same areas as the above-ground biomass using a soil corer (diameter $7 \mathrm{~cm}$ ). Living roots (fine and coarse roots) were picked and washed. After drying $\left(+65^{\circ} \mathrm{C}\right)$ for $24 \mathrm{~h}$, DW was measured.

To analyse the performance of the crop, water use efficiency (WUE) was determined following Law et al. (2002). For this purpose, evapotranspiration (ET) was determined by dividing LE with the latent heat of vaporization $\left(\mathrm{L}=2500 \mathrm{~kJ} \mathrm{~kg}^{-1}\right)$. Monthly sums of GPP and ET from the May to September period were obtained and WUE was determined as the slope of the linear regression between monthly GPP and ET. The Bowen ratio was calculated from daytime (PAR > $20 \mu \mathrm{mol} \mathrm{m}^{-2} \mathrm{~s}^{-1}$ ) measured $H$ and LE fluxes.

\subsection{Analysis of environmental factors governing $\mathrm{CO}_{2}$ exchange}

The relationship between GPP and PAR was examined on a monthly basis from mid-May to September separately for 2010 and 2011. Prior to the analysis, PAR data were binned at an interval of $10 \mu \mathrm{mol} \mathrm{m}^{-2} \mathrm{~s}^{-1}$. The bin-averaged values of GPP were plotted against PAR and the data were fitted with a rectangular hyperbolic model of the form (e.g. Thornley and Johnson, 1990)

$\mathrm{GPP}=\frac{\mathrm{GP}_{\max } \cdot \mathrm{PAR} \cdot \alpha}{\mathrm{GP}_{\max }+\mathrm{PAR} \cdot \alpha}$, 
where $\mathrm{GP}_{\max }\left(\mu \mathrm{mol} \mathrm{m}{ }^{-2} \mathrm{~s}^{-1}\right)$ is the theoretical maximum rate of photosynthesis at infinite PAR and $\alpha$ is the apparent quantum yield. Additionally, data with PAR levels greater than $1000 \mu \mathrm{mol} \mathrm{m} \mathrm{m}^{-2} \mathrm{~s}^{-1}$ were used to study the relationship between GPP and air temperature, VPD and soil moisture. To analyse the relationship between GPP and GA and also LAI, a weekly averaged GPP was constructed for those weeks when the plant variables were available. These data were fitted with a linear regression.

To be able to compare the results in detail with the earlier findings on RCG at an organic soil site in Finland (Shurpali et al., 2010) another regression model was used to assess the relationship between TER and soil temperature, nighttime measured NEE (PAR $<5 \mu \mathrm{mol} \mathrm{m}{ }^{-2} \mathrm{~s}^{-1}$ ) from May to September separately for 2010 and 2011 was used. Prior to the analysis, the data were binned with soil temperature at $2.5 \mathrm{~cm}$ depth (from 0 to 21.5 with a $0.5^{\circ} \mathrm{C}$ interval). The binaveraged values of TER were plotted against soil temperature and the data were fitted with an exponential regression model of the form (e.g. Shurpali et al., 2009)

$\mathrm{TER}=R_{10} \cdot Q_{10}^{\left(T_{\mathrm{s}} / T_{10}\right)}$,

where $T_{\mathrm{s}}$ is the measured soil temperature $\left({ }^{\circ} \mathrm{C}\right)$ at 2.5 depth, $T_{10}=10^{\circ} \mathrm{C}$ and the fitted parameters are $R_{10}$ (base respiration, $\mu \mathrm{mol} \mathrm{m} \mathrm{m}^{-2} \mathrm{~s}^{-1}$, at $10^{\circ} \mathrm{C}$ ) and $Q_{10}$ (the temperature sensitivity coefficient). To analyse the relationship between TER and vegetation, we constructed weekly means from daily TER values for the weeks during which GA was estimated for 2010 and 2011. To assess the relationship between GPP and TER, daily sums of TER and GPP from May to September separately for 2010 and 2011 were used in the linear regression analysis.

\subsection{Comparison site characteristics}

The comparison site with organic soil has been intensively studied and several papers report results from it (e.g. Shurpali et al., 2008; Hyvönen et al., 2009; Shurpali et al., 2009, 2010, 2013; Gong et al., 2013). The comparison site is located in eastern Finland $\left(62^{\circ} 30^{\prime} \mathrm{N}, 30^{\circ} 30^{\prime} \mathrm{E}, 110 \mathrm{~m}\right.$ above mean sea level). Long-term (30 years, reference period 1981-2010) annual air temperature in the region is $3.0^{\circ} \mathrm{C}$ and the annual precipitation in the region is $613 \mathrm{~mm}$. The area was originally an ombrotrophic Sphagnum fuscum pine bog (for more details, see Biasi et al., 2008). From 1976 onwards the site was prepared for peat extraction - i.e. it was drained and the vegetation was removed. Peat extraction was started in 1978. In 2001, when the peat depths were between 20 and $85 \mathrm{~cm}$, a 15 ha area was sown with RCG (cv. "Palaton"). Since then, the site has been annually fertilized with $50 \mathrm{~kg} \mathrm{~N} \mathrm{ha}^{-1}$, $14 \mathrm{~kg} \mathrm{Pha}^{-1}$ and $46 \mathrm{~kg} \mathrm{Kha}^{-1}$. Lime was added as dolomite limestone $\left(\mathrm{CaMg}\left(\mathrm{CO}_{3}\right)_{2}\right)$ at the rate of $7.8 \mathrm{tha}^{-1}$ in 2001 and 2006.

The average surface peat characteristics were as follows: $\mathrm{pH} 5.4$, bulk density $0.42 \mathrm{~g} \mathrm{~m}^{-3}$ and $\mathrm{C}: \mathrm{N}$ ratio 40.3 (Shur- pali et al., 2008). The climatic conditions during the years 2004-2007 at the site were such that the annual air temperature was $2.7,3.7,3.1$ and $3.2^{\circ} \mathrm{C}$ and annual precipitation was 862, 544, 591, $700 \mathrm{~mm}$ in 2004, 2005, 2006 and 2007, respectively (Hyvönen et al., 2009). During May-September period, the precipitation was 554, 246, 249 and $423 \mathrm{~mm}$ in 2004, 2005, 2006 and 2007, respectively. The difference to the long-term mean $(312 \mathrm{~mm})$ was approximately $20 \%$ during the dry years (2005 and 2006) and 36 and $78 \%$ during the wet years (2004 and 2007, respectively). Water table level was on average $0.65 \mathrm{~m}$, varying from 0.4 to $0.7 \mathrm{~m}$ during the years (Hyvönen et al., 2009). The volumetric water content (VWC) at $30 \mathrm{~cm}$ depth was always high and did not vary between the years. The VWC at surface layers ( 2.5 and $10 \mathrm{~cm}$ depths) fluctuated in response to precipitation events and ranged from 0.1 to $0.8 \mathrm{~m}^{3} \mathrm{~m}^{-3}$. The biomass at the site was used for burning purpose and, therefore, it was harvested in the spring. The spring-harvested yields were 3700, 2000, 3600 and $4700 \mathrm{~kg} \mathrm{ha}^{-1}$ in 2004, 2005, 2006 and 2007, respectively (Shurpali et al., 2009). The $\mathrm{CO}_{2}$ exchange was measured using an open-path EC system and details of the measurements and data processing can be found in Shurpali et al. (2009).

\section{Results}

\subsection{Seasonal climate and crop growth}

The mean annual air temperature at the study site was 3.5, 2.2 and $4.5^{\circ} \mathrm{C}$ in 2009,2010 and 2011 , respectively, with the daily means varying from -30.0 to $+27.1^{\circ} \mathrm{C}$ (Fig. 1a). Annual precipitation was 421,521 and $670 \mathrm{~mm}$ in 2009, 2010 and 2011, respectively. In May-September period the precipitation was 40 and $28 \%$ lower in $2009(192 \mathrm{~mm})$ and 2010 $(228 \mathrm{~mm})$ than the long-term mean. Precipitation was about the same as the long-term mean in 2011 (327 mm, Fig. 1b). The growing season is defined as having commenced when the mean daily air temperature exceeds $5^{\circ} \mathrm{C}$ for 5 consecutive days with no snow and ended when the mean daily air temperature is below $5^{\circ} \mathrm{C}$ on 5 consecutive days. Growing season commenced on 1 May 2009, 9 May 2010 and 23 April 2011 and lasted 152, 156 and 182 days in the three consecutive years.

The daily averaged VWC ranged from 0.12 to $0.54 \mathrm{~m}^{3} \mathrm{~m}^{-3}$, from 0.09 to $0.37 \mathrm{~m}^{3} \mathrm{~m}^{-3}$ and from 0.11 to $0.45 \mathrm{~m}^{3} \mathrm{~m}^{-3}$ in 2009,2010 and 2011 , respectively (Fig. 1c). The summer maxima were recorded at $2.5 \mathrm{~cm}$ depth in July $2010\left(20.9^{\circ} \mathrm{C}\right)$ and $2011\left(19.1^{\circ} \mathrm{C}\right)$ (Fig. 1d). During the winter 2009-2010 and 2010-2011 the soil temperatures were close to zero. The lowest soil temperatures were recorded at $2.5 \mathrm{~cm}$ depth in December $2009\left(-7.5^{\circ} \mathrm{C}\right)$ and November $2010\left(-3.4^{\circ} \mathrm{C}\right)$.

The estimated evapotranspiration (ET), was 110,330 and $370 \mathrm{~mm}$ in August-September 2009, May-September 2010 


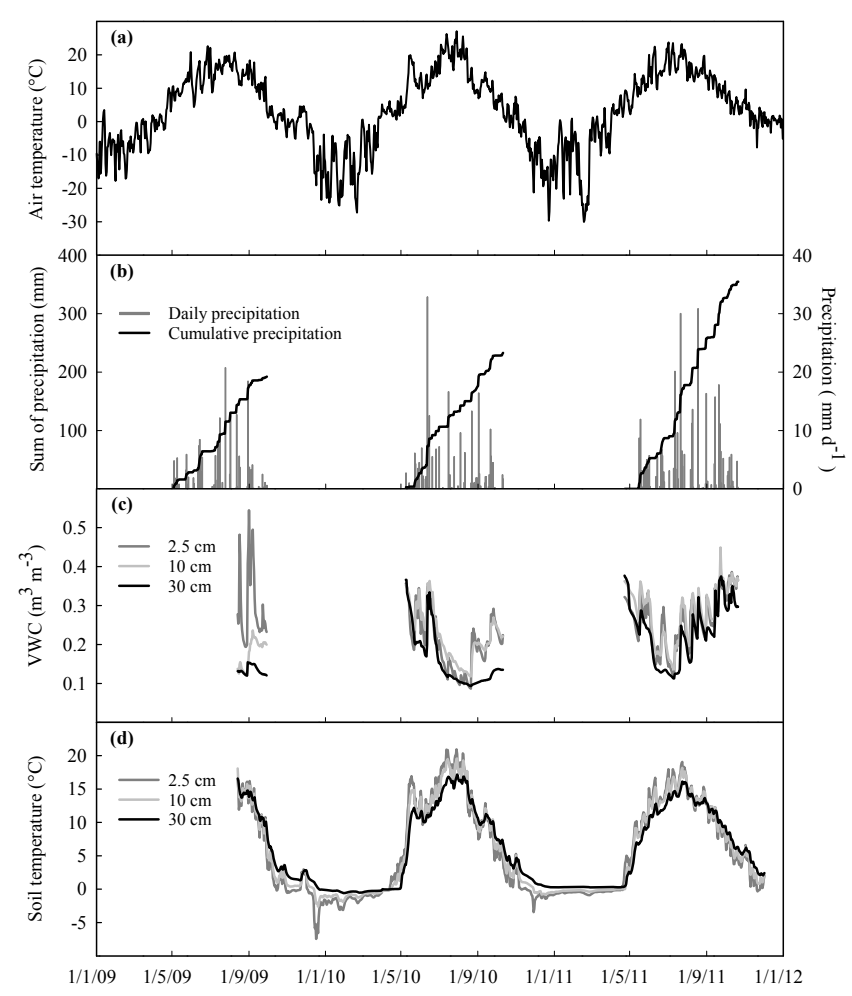

Figure 1. Climatic conditions at the study site during the measurement years. (a) Daily averaged air temperature $\left({ }^{\circ} \mathrm{C}\right)$ during 2009 2011, (b) Daily precipitation ( $\mathrm{mm} \mathrm{d}^{-1}$, grey line) and its cumulative sum ( $\mathrm{mm}$, black line) during the growing seasons. (c) Daily averaged volumetric water content $\left(\mathrm{VWC}, \mathrm{m}^{3} \mathrm{~m}^{-3}\right.$ ) at $2.5 \mathrm{~cm}$ (dark grey line), $10 \mathrm{~cm}$ (light grey line) and $30 \mathrm{~cm}$ (black line) during the growing seasons, from 14 August 2009 onwards. (d) Soil temperatures $\left({ }^{\circ} \mathrm{C}\right.$ ) at the $2.5 \mathrm{~cm}$ (dark grey line), $10 \mathrm{~cm}$ (light grey line) and $30 \mathrm{~cm}$ (black line) depths as daily means from 14 August 2009 until 2 December 2011.

and May-September 2011, respectively. During those time periods, the ecosystem used more water than was received through rainfall as the corresponding precipitation amounts were 80, 220 and $320 \mathrm{~mm}$ in 2009, 2010 and 2011, respectively. A clear linear relationship was found between GPP and ET (adjusted $R^{2}=0.73, p<0.01, n=12$ ) during the May-September period in 2010 and 2011. The water use efficiency (WUE) of the RCG cultivation determined from this relationship was $12 \mathrm{~g} \mathrm{CO}_{2}$ per $\mathrm{kg} \mathrm{H}_{2} \mathrm{O}$. Averaged daytime Bowen ratio was 0.18 and 0.28 during the May-September period in 2010 and 2011, respectively.

During the first growing season (2009), the vegetation development was slow and the maximum plant height was low when compared to the subsequent years $(0.6,1.7$ and $1.8 \mathrm{~m}$ in 2009, 2010 and 2011, respectively). In the following years, the initial sprouting in early spring was followed by vigorous plant growth which lasted about 9 weeks. The rapid plant growth resulted in a steep increase in green area (GA) and leaf area indices (LAI) in 2010 and 2011 (Fig. 2b, c). Both

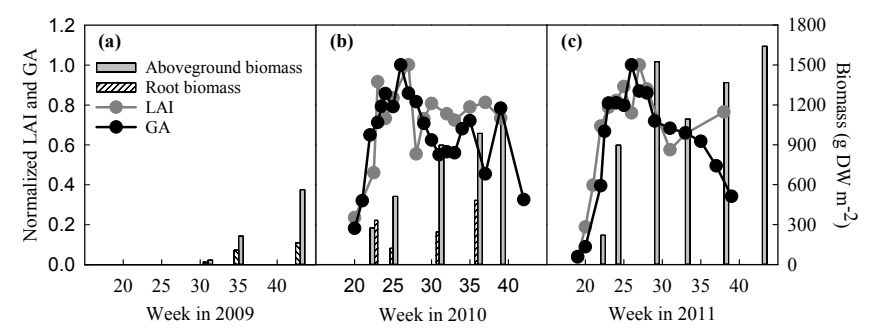

Figure 2. Vegetation parameters determined on the reed canary grass (RCG) cultivation. Approximately monthly determined above-ground (grey bars) and root biomass (hatched bars) in g dry weight (DW) $\mathrm{m}^{-2}$ between week 15 and 45 in (a) 2009, (b) 2010 and (c) 2011. Also approximately weekly determined normalized green area index (GA, black dots) and leaf area index (LAI, grey dots) for (b) 2010 and (c) 2011 is shown.

GA and LAI levelled off in the beginning of June. The maximum above-ground biomass was recorded at the end of the season $\left(560,1100\right.$ and $1600 \mathrm{~g} \mathrm{DW} \mathrm{m}^{-2}$ in 2009, 2010 and 2011, respectively) (Fig. 2a, b and c). The maximum root biomass was $480 \mathrm{~g} \mathrm{DW} \mathrm{m}^{-2}$ in 2010 (Fig. 2b). Depending on the sampling occasion, 70 to $80 \%$ of the roots were distributed within the $0-10 \mathrm{~cm}$ depth. The crop yield was 6200 and $6700 \mathrm{~kg} \mathrm{DW} \mathrm{ha}^{-1}$ in 2010 and 2011, respectively.

\section{2 $\mathrm{CO}_{2}$ exchange patterns}

\subsubsection{Measured net ecosystem $\mathrm{CO}_{2}$ and energy exchange}

Measured $30 \mathrm{~min}$ values of NEE, $H$ and LE during 2009, 2010 and 2011 prior to the gap filling are shown in Fig. 3. In 2009, the NEE measurements began 45 days after the sowing in mid-June. The maximum amplitude of the diurnal NEE cycle varied from -26 to $20 \mu \mathrm{mol} \mathrm{m}^{-2} \mathrm{~s}^{-1}$ during the growing season in 2009. The amplitude of the diurnal NEE cycle was noticeable around mid-May onwards until November in 2010 and 2011. The maximum amplitude of diurnal NEE cycle varied from -31 to $18 \mu \mathrm{mol} \mathrm{m}^{-2} \mathrm{~s}^{-1}$ and from -37 to $20 \mu \mathrm{mol} \mathrm{m}{ }^{-2} \mathrm{~s}^{-1}$ during the growing seasons in 2010 and 2011, respectively (Fig. 3a). Outside the growing seasons, respiratory losses dominated the net $\mathrm{CO}_{2}$ balance. The ecosystem $\mathrm{CO}_{2}$ loss was $0.62 \mu \mathrm{mol} \mathrm{m}^{-2} \mathrm{~s}^{-1}$ from October 2009 to mid-May 2010, $0.76 \mu \mathrm{mol} \mathrm{m}^{-2} \mathrm{~s}^{-1}$ during a similar period in 2010-2011 and $1.1 \mu \mathrm{mol} \mathrm{m}^{-2} \mathrm{~s}^{-1}$ for a shorter time period in 2011 (November and December). The diurnal LE cycle had the maximum amplitude during the summer months and ranged from -30 to 400 , from 0 to 400 and from 0 to $600 \mathrm{~W} \mathrm{~m}^{-2}$ in 2009, 2010 and 2011, respectively. LE was close to zero during the non-growing season. The amplitude of diurnal $H$ cycle was at the maximum during the summer months and ranged from -50 to 130 , from -100 to 210 and from -100 to $190 \mathrm{~W} \mathrm{~m}^{-2}$ in 2009,2010 and 2011 , 


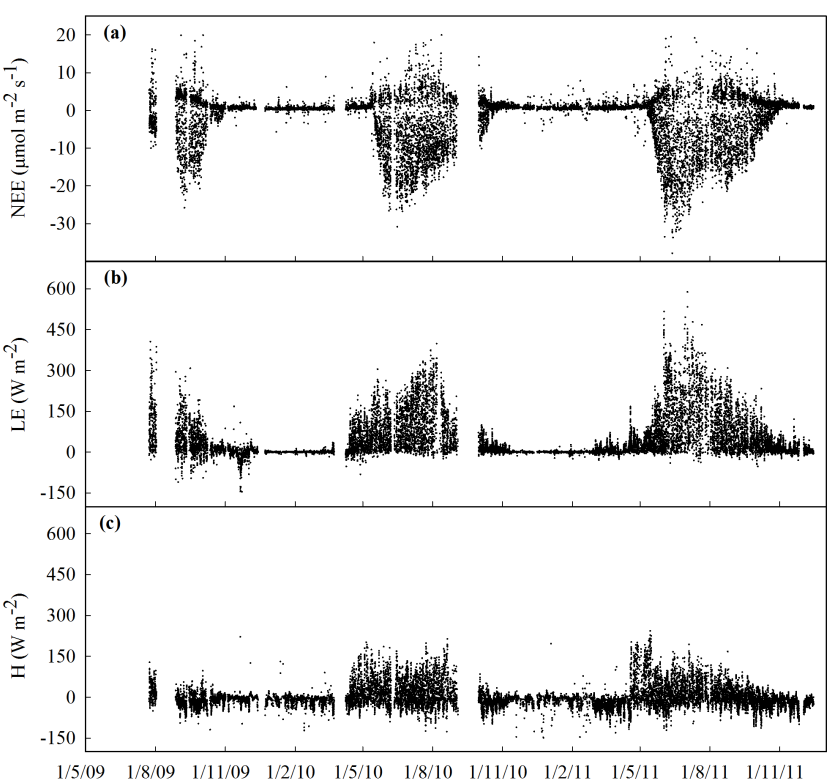

Figure 3. Measured $\mathrm{CO}_{2}$ and energy fluxes from July 2009 to December 2011. (a) Net ecosystem $\mathrm{CO}_{2}$ exchange (NEE, $\mu \mathrm{mol} \mathrm{m} \mathrm{m}^{-2} \mathrm{~s}^{-1}$ ). (b) Latent heat flux (LE, $\mathrm{W} \mathrm{m}^{-2}$ ). (c) Sensible heat flux $\left(H, \mathrm{~W} \mathrm{~m}^{-2}\right)$.

respectively. $H$ ranged from -60 to $20 \mathrm{~W} \mathrm{~m}^{-2}$ during the non-growing seasons.

\subsubsection{Diurnal trends}

To examine the diurnal trends, the data on air temperature, VPD, PAR and NEE in June 2010 and 2011 were averaged to generate half-hour diurnal means (Fig. 4). In both years, June presented conditions of high $\mathrm{CO}_{2}$ uptake during the day and of $\mathrm{CO}_{2}$ loss at night. Air temperature was lower in 2010 than in 2011 but both years showed typical diurnal patterns with minimum values during early morning hours and maximum values late in the afternoon (Fig. 4a). Similarly, the VPD was lower in 2010 than 2011 (Fig. 4b). The maximum in VPD $(0.96 \mathrm{kPa})$ occurred late afternoon in 2010 whereas in 2011 the maximum $(0.89 \mathrm{kPa})$ occurred around noon. In both years, the amplitude of diurnal mean of temperature and VPD was moderate. The mean diurnal pattern of NEE was similar between 2010 and 2011 and the patterns were fairly symmetrical (Fig. 4d). During the night-time, from 22:00 to about 02:00 (UTC+2), $\mathrm{CO}_{2}$ exchange between the ecosystem and atmosphere was constant and dominated by respiration. Mean NEE during this time was $4.5 \mu \mathrm{mol} \mathrm{m}^{-2} \mathrm{~s}^{-1}$ in 2010 and $6.6 \mu \mathrm{mol} \mathrm{m}^{-2} \mathrm{~s}^{-1}$ in 2011. In the morning hours, with increasing PAR (Fig. 4c), NEE began to decline and the light compensation point occurred at a PAR level of about $200 \mu \mathrm{mol} \mathrm{m}^{-2} \mathrm{~s}^{-1}$ at around 05:00 (UTC+2). After this, the uptake dominated the $\mathrm{CO}_{2}$ balance. The peaks in mean NEE occurred around 12:00 (UTC+2) at the same time as the peaks in the mean PAR. The maximum mean NEE in June

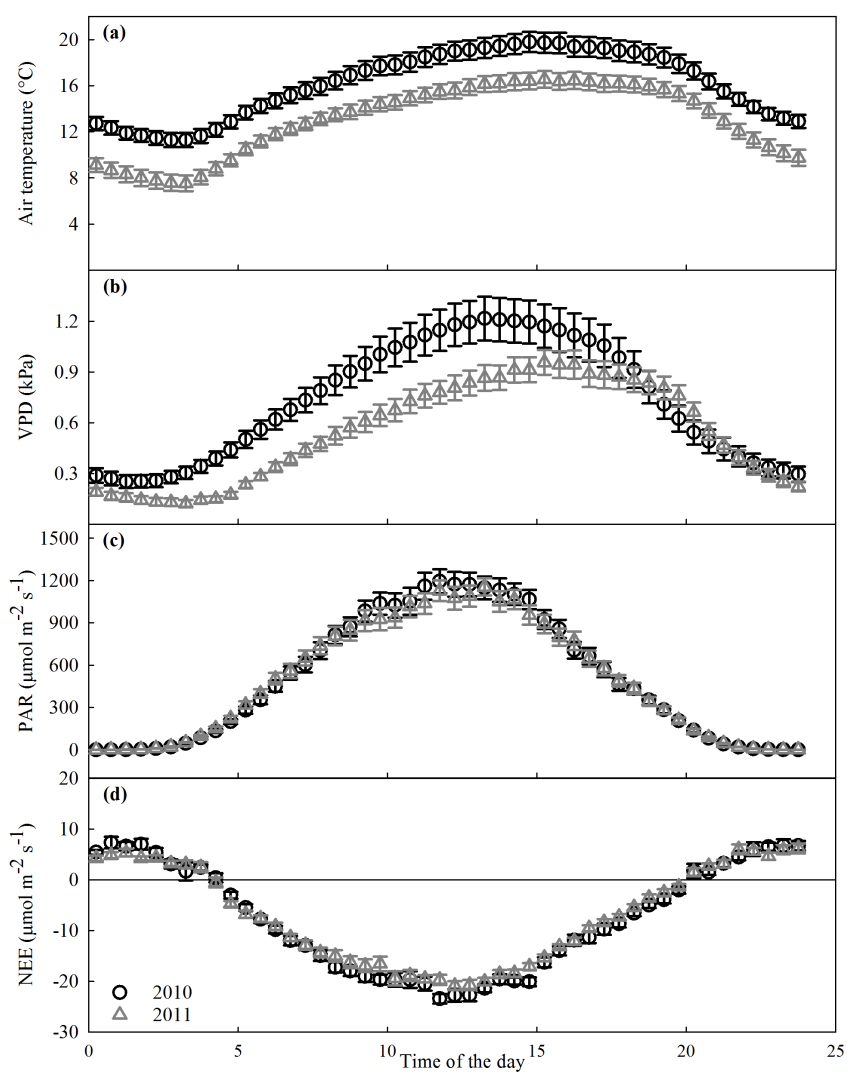

Figure 4. Mean diurnal variations in June 2010 (open grey triangles) and 2011 (open black circles). (a) Air temperature $\left({ }^{\circ} \mathrm{C}\right)$. (b) Vapour pressure deficit (VPD, $\mathrm{kPa}$ ). (c) Photosynthetically active radiation $\left(\mathrm{PAR}, \mu \mathrm{mol} \mathrm{m} \mathrm{m}^{-2} \mathrm{~s}^{-1}\right.$ ). (d) Net ecosystem $\mathrm{CO}_{2}$ exchange $\left(\mathrm{NEE}, \mu \mathrm{mol} \mathrm{m}{ }^{-2} \mathrm{~s}^{-1}\right)$. Data are half-hour means with standard error.

was -21 and $-23 \mu \mathrm{mol} \mathrm{m}{ }^{-2} \mathrm{~s}^{-1} 2010$ and 2011 , respectively. With declining PAR levels, the plant $\mathrm{CO}_{2}$ uptake also declined. The secondary light compensation point occurred at around 20:00 (UTC+2).

\subsubsection{Daily patterns}

Seasonal patterns of daily sums of GPP, TER and NEE are shown in Fig. 5. From the start of NEE measurements in late July to mid-August in 2009, the site was a net source of $\mathrm{CO}_{2}$ to the atmosphere. By mid-August, GPP began to overwhelm TER turning the site into a $\mathrm{CO}_{2}$ sink. During the growing season, the maximum daily values of NEE, TER and GPP were $-5.8,9.7$ and $-10.5 \mathrm{~g} \mathrm{C} \mathrm{m}^{-2} \mathrm{~d}^{-1}$, respectively. The uptake of $\mathrm{CO}_{2}$ ended by late October. Respiration levelled off by mid-December. From mid-December 2009 until May 2010, TER remained low at an average rate of $0.46 \mathrm{~g} \mathrm{C} \mathrm{m}^{-2} \mathrm{~d}^{-1}$. In May 2010 and 2011, the daily GPP and TER were clearly distinguishable. During the growing season, the maximum daily values of NEE, TER and GPP were $-9.4,11.5$ and $-18.0 \mathrm{~g} \mathrm{C} \mathrm{m}^{-2} \mathrm{~d}^{-1}$, respectively. Res- 


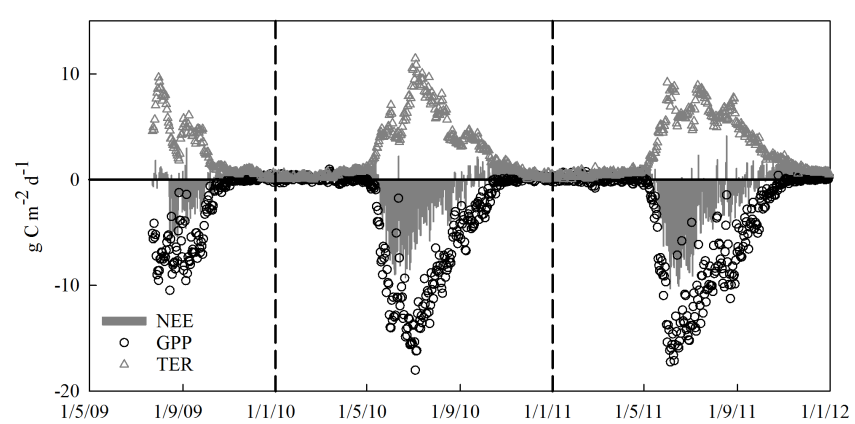

Figure 5. The components of daily $\mathrm{CO}_{2}$ exchange over the measurement period. Daily sum of net ecosystem $\mathrm{CO}_{2}$ exchange (NEE, grey bars), gross primary production (GPP, open black circles) and total ecosystem respiration (TER, open grey triangles) as $\mathrm{g} \mathrm{C} \mathrm{m}^{-2} \mathrm{~d}^{-1}$. Horizontal solid black lines show the zero level and vertical dashed black lines mark beginning of the year.

piration levelled off at the end of November and TER remained low during the wintertime until the beginning of May in 2011. Wintertime TER averaged $0.51 \mathrm{~g} \mathrm{C} \mathrm{m}^{-2} \mathrm{~d}^{-1}$. During the growing season in 2011, the maximum daily values of NEE, TER and GPP were similar to those in 2010. Respiration levelled off by the beginning of December, with an average value of $0.76 \mathrm{~g} \mathrm{C} \mathrm{m}^{-2} \mathrm{~d}^{-1}$ for December 2011.

\subsection{Factors controlling $\mathrm{CO}_{2}$ exchange}

\subsubsection{Gross photosynthesis}

The strong relationships between bin-averaged GPP and PAR from May to September in 2010 and 2011 can be seen in Fig. 6a-e. The rectangular hyperbolic model provided good fits to the data (adjusted $R^{2}>0.90$, Table 1 ) except in May 2010 and 2011 (adjusted $R^{2}=0.52$ and $R^{2}=0.76$, respectively) and all relationships were statistically significant $(p<0.01)$. There was no clear indication of GPP saturation even at PAR levels close to $1800 \mu \mathrm{mol} \mathrm{m}^{-2} \mathrm{~s}^{-1}$ during June and July (Fig. 6a-e). The estimated monthly $\mathrm{GP}_{\max }$ values are shown in Table 1. There were no differences in the $\mathrm{GP}_{\max }$ values for May, June and July during 2010 and 2011, whereas in August and especially in September, the monthly average $\mathrm{GP}_{\max }$ was higher in 2011 than in 2010. The seasonal variation in monthly $\mathrm{GP}_{\max }$ values was clear (Table 1) and in May, September and August, the monthly averaged $\mathrm{GP}_{\max }$ were low while the maximum values were observed in June and July. The range of the monthly $\alpha$-values (quantum yield) varied from -0.04 to -0.06 in 2010 and from -0.05 to -0.07 in 2011. Further analysis under conditions with PAR level greater than $1000 \mu \mathrm{mol} \mathrm{m}^{-2} \mathrm{~s}^{-1}$ revealed that effect of other climatic variables such as air temperature, the VPD and soil moisture on GPP was masked by the dominant role of PAR.

We studied the relationships between weekly averaged GPP, GA and LAI. GPP increased with an increasing GA implying a positive linear relationship between these variables;

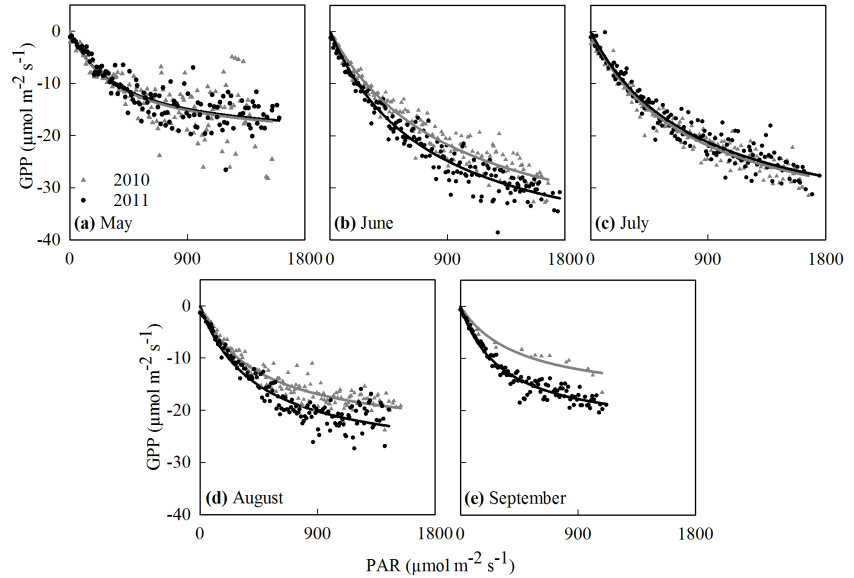

Figure 6. Relationship of gross primary production (GPP) to incident photosynthetically active radiation (PAR). Measured monthly (mid-May-September) GPP $\left(\mu \mathrm{mol} \mathrm{m}{ }^{-2} \mathrm{~s}^{-1}\right)$ averaged with binned (steps of $10 \mu \mathrm{mol} \mathrm{m} \mathrm{m}^{-2} \mathrm{~s}^{-1}$ ) PAR $\left(\mu \mathrm{mol} \mathrm{m}{ }^{-2} \mathrm{~s}^{-1}\right)$ for 2010 (closed grey triangles) and 2011 (closed black circles). Data are fitted with nonlinear regression $\left(\mathrm{GPP}=\left(\mathrm{GP}_{\max } \times \mathrm{PAR} \times \alpha /\left(\mathrm{GP}_{\max }+\mathrm{PAR} \times \alpha\right)\right)\right.$ between GPP and PAR (fit results in Table 1). Only measured data were used in the analysis.

the adjusted $R^{2}$ value of the regression was 0.28 in 2010 $(p=0.011)$ and 0.45 in $2011(p<0.01)$. A relationship between GPP and LAI was not evident in 2010; however, they were better correlated in 2011 with an adjusted $R^{2}$ value of $0.42(p<0.01)$.

\subsubsection{Ecosystem respiration}

There was a clear relationship between bin-averaged nighttime TER and soil temperature from May to September in 2010 and 2011 (Fig. 7a). The exponential regression model provided good fits to the data (adjusted $R^{2} 0.71$ and 0.69 for 2010 and 2011, respectively) and the relationships were statistically significant $(p<0.01)$. The $Q_{10}$ values were similar between the 2 years $\left(2.17\right.$ and 2.35 ). The $R_{10}$ values were 1.75 and $1.66 \mu \mathrm{mol} \mathrm{m}^{-2} \mathrm{~s}^{-1}$ in 2010 and 2011, respectively. Additionally, TER increased with the increasing GA in 2010 (Fig. 7b), however, the linear correlation was not statistically significant (adjusted $R^{2}=0.16, p=0.053$ ). TER and GA were better correlated in 2011 (adjusted $R^{2}=0.51, p<0.01$ ). There was a strong positive linear relationship between TER and GPP $(p<0.01)$ in both years (Fig. 7c). GPP explained 82 and $75 \%$ of the variation in the TER in 2010 and 2011, respectively.

\subsection{Annual balance}

The estimated annual balances of TER, GPP and NEE are shown in Table 2. The site acted as a $\mathrm{CO}_{2}$ sink during the studied years and the annual NEE was $-56.7,-262$ 
Table 1. Monthly fit results of a rectangular hyperbolic model together with average climatic conditions - the fit results between gross primary production (GPP, $\mu \mathrm{mol} \mathrm{m} \mathrm{m}^{-2} \mathrm{~s}^{-1}$ ) binned with photosynthetically active radiation (PAR, $\mu \mathrm{mol} \mathrm{m}^{-2} \mathrm{~s}^{-1}$, bins from 0 to $1800 \mu \mathrm{mol} \mathrm{m}^{-2} \mathrm{~s}^{-1}$ with an interval of $10 \mu \mathrm{mol} \mathrm{m}{ }^{-2} \mathrm{~s}^{-1}$ ) from mid-May to September in 2010 and 2011. A rectangular hyperbolic model of the form $\mathrm{GPP}=\left(\mathrm{GP}_{\max } \times \mathrm{PAR} \times \alpha /\left(\mathrm{GP}_{\max }+\mathrm{PAR} \times \alpha\right)\right.$, where $\mathrm{GP}_{\max }\left( \pm \mathrm{SE}, \mu \mathrm{mol} \mathrm{m}{ }^{-2} \mathrm{~s}^{-1}\right)$ is the theoretical maximum rate of photosynthesis at infinite PAR and $\alpha( \pm \mathrm{SE})$ is the apparent quantum yield - i.e. the initial slope of the light response curve was used. Adjusted $R^{2}$ of regression and number of PAR bins $(n)$ are shown. Also monthly average $( \pm \mathrm{SD})$ of air temperature $\left(T,{ }^{\circ} \mathrm{C}\right)$, volumetric water content $\left(\mathrm{VWC}, \mathrm{m}^{3} \mathrm{~m}^{-3}\right)$ at $2.5 \mathrm{~cm}$ depth and vapour pressure deficit (VPD, $\mathrm{kPa}$ ) are shown together with number of rain event days (when precipitation $>0.2 \mathrm{~mm}$ ) in month, precipitation sum (prec., $\mathrm{mm} \mathrm{mo}^{-1}$ ) and monthly averaged green area $\left(\mathrm{GA}, \mathrm{m}^{2} \mathrm{~m}^{-2}\right.$ ) and leaf area (LAI, $\left.\mathrm{m}^{2} \mathrm{~m}^{-2}\right)$ indices.

\begin{tabular}{|c|c|c|c|c|c|c|c|c|c|c|c|}
\hline Month & $\begin{array}{r}\text { GPmax } \\
\left(\mu \mathrm{mol} \mathrm{m}{ }^{-2} \mathrm{~s}^{-1}\right)\end{array}$ & $\alpha$ & $R^{2}$ & $n$ & $\begin{array}{r}T \\
\left({ }^{\circ} \mathrm{C}\right)\end{array}$ & $\begin{array}{r}\mathrm{VWC} \\
\left(\mathrm{m}^{3} \mathrm{~m}^{-3}\right)\end{array}$ & $\begin{array}{l}\mathrm{VPD} \\
(\mathrm{kPa})\end{array}$ & $\begin{array}{r}\text { Prec. } \\
\text { events }\end{array}$ & sum & GA & LAI \\
\hline \multicolumn{12}{|l|}{2010} \\
\hline May & $-21.5 \pm 1.7$ & $-0.057 \pm 0.009$ & 0.52 & 133 & $14.3 \pm 5.3$ & $0.26 \pm 0.05$ & $0.65 \pm 0.6$ & 7 & 23 & 8.7 & 1.8 \\
\hline Jun & $-44.5 \pm 1.7$ & $-0.047 \pm 0.002$ & 0.93 & 158 & $13.0 \pm 4.6$ & $0.26 \pm 0.05$ & $0.54 \pm 0.4$ & 9 & 72 & 19.0 & 4.3 \\
\hline Jul & $-40.1 \pm 1.1$ & $-0.053 \pm 0.002$ & 0.95 & 163 & $21.0 \pm 4.7$ & $0.14 \pm 0.03$ & $0.85 \pm 0.7$ & 7 & 34 & 17.2 & 4.0 \\
\hline Aug & $-25.2 \pm 0.7$ & $-0.057 \pm 0.003$ & 0.91 & 148 & $15.8 \pm 6.2$ & $0.14 \pm 0.05$ & $0.53 \pm 0.5$ & 14 & 42 & 14.0 & 3.9 \\
\hline Sep & $-18.1 \pm 2.2$ & $-0.040 \pm 0.007$ & 0.93 & 19 & $9.8 \pm 3.9$ & $0.21 \pm 0.04$ & $0.14 \pm 0.2$ & 16 & 53 & 14.1 & 4.0 \\
\hline \multicolumn{12}{|l|}{2011} \\
\hline May & $-21.2 \pm 1.0$ & $-0.056 \pm 0.005$ & 0.76 & 134 & $11.2 \pm 4.0$ & $0.30 \pm 0.03$ & $0.45 \pm 0.4$ & 11 & 38 & 5.7 & 1.8 \\
\hline Jun & $-45.8 \pm 1.4$ & $-0.060 \pm 0.002$ & 0.94 & 163 & $16.1 \pm 4.9$ & $0.21 \pm 0.05$ & $0.73 \pm 0.6$ & 11 & 41 & 16.2 & 4.6 \\
\hline Jul & $-40.4 \pm 1.5$ & $-0.050 \pm 0.002$ & 0.92 & 154 & $19.1 \pm 4.4$ & $0.20 \pm 0.06$ & $0.65 \pm 0.5$ & 11 & 91 & 15.5 & 5.3 \\
\hline Aug & $-29.9 \pm 1.0$ & $-0.069 \pm 0.004$ & 0.90 & 141 & $15.0 \pm 3.5$ & $0.25 \pm 0.05$ & $0.38 \pm 0.4$ & 10 & 80 & 12.5 & 3.7 \\
\hline Sep & $-24.2 \pm 0.7$ & $-0.074 \pm 0.004$ & 0.94 & 103 & $11.1 \pm 3.3$ & $0.31 \pm 0.04$ & $0.20 \pm 0.2$ & 13 & 70 & 8.0 & 4.3 \\
\hline
\end{tabular}
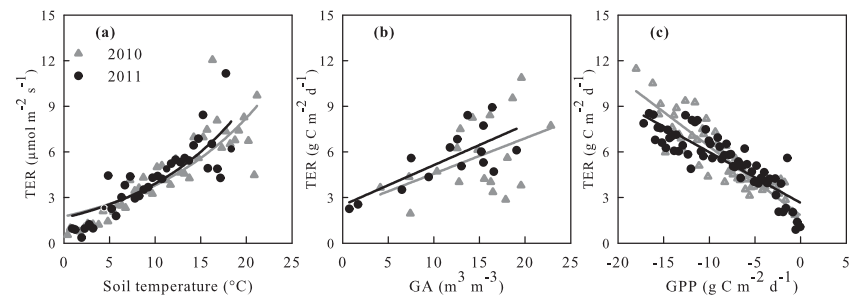

Figure 7. Relationships between total ecosystem respiration (TER) and environmental variables. (a) TER $\left(\mu \mathrm{mol} \mathrm{m}{ }^{-2} \mathrm{~s}^{-1}\right)$ and soil temperature $\left({ }^{\circ} \mathrm{C}\right)$ at $2.5 \mathrm{~cm}$ depth (binned with steps of $0.5^{\circ} \mathrm{C}$ ) in May-September period fitted with an exponential nonlinear regression (TER $=R_{10} \times Q_{10}^{\left(T_{\mathrm{S}} / T_{10}\right)}$, where $R_{10}$ and $Q_{10}$ are fitted parameters). (b) Weekly averaged TER $\left(\mathrm{g} \mathrm{C} \mathrm{m}^{-2} \mathrm{~d}^{-1}\right)$ and green area index $\left(\mathrm{GA}, \mathrm{m}^{3} \mathrm{~m}^{-3}\right)$ in May-October period fitted with linear regression. (c) Daily values of TER $\left(\mathrm{g} \mathrm{C} \mathrm{m}^{-2} \mathrm{~d}^{-1}\right)$ and gross primary production (GPP, $\mathrm{g} \mathrm{C} \mathrm{m}^{-2} \mathrm{~d}^{-1}$, binned with steps of $0.25 \mathrm{~g} \mathrm{C} \mathrm{m}^{-2} \mathrm{~d}^{-1}$ ) in May-September period fitted with linear regression. Closed grey triangles are data for 2010 and closed black circles for 2011. Fit results are given in the text.

and $-256 \mathrm{~g} \mathrm{C} \mathrm{m}^{-2}$ in 2009 (23 July to 31 December), 2010 and 2011, respectively. The pattern in NEE accumulation is shown in Fig 8. During the 3-week time period from late July to mid-August 2009 , the site acted as a source of atmospheric $\mathrm{CO}_{2}$. After the transition from a source to a sink in mid-August 2009, the site sequestered atmosphere $\mathrm{CO}_{2}$ for about 60 days leading to a negative cumulative NEE of $-160 \mathrm{~g} \mathrm{C} \mathrm{m}^{-2}$. During the winter dormancy period (from

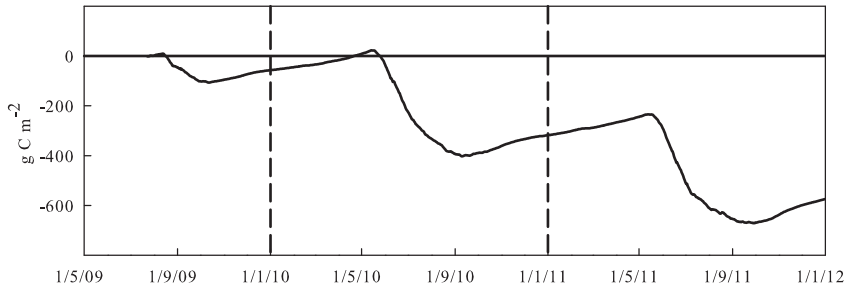

Figure 8. Cumulative NEE over the study period. Negative values indicate uptake of $\mathrm{CO}_{2}$ and positive values emission to the atmosphere. Horizontal solid black lines show the zero level and vertical dashed black lines mark beginning of the year.

late October 2009 to May 2010) the site lost $183 \mathrm{~g} \mathrm{C} \mathrm{m}^{-2}$ and the cumulative $\mathrm{NEE}$ was $23 \mathrm{~g} \mathrm{C} \mathrm{m}^{-2}$. After this, the site was an annual $\mathrm{CO}_{2}$ sink, since the summer time uptake was higher than the wintertime $\mathrm{CO}_{2}$ loss. In 2010, $\mathrm{CO}_{2}$ uptake period lasted approximately 120 days (May to midSeptember) and in mid-September the cumulative NEE was $-403 \mathrm{~g} \mathrm{C} \mathrm{m}^{-2}$. During the second winter dormancy, from mid-September 2010 to mid-May 2011, the site lost approximately $168 \mathrm{~g} \mathrm{C} \mathrm{m}^{-2}$. In 2011, the $\mathrm{CO}_{2}$ uptake period lasted about 135 days (from mid-May to early October) with a cumulative NEE of $-679 \mathrm{~g} \mathrm{C} \mathrm{m}^{-2}$ by the end of this season. By the end of 2011, the cumulative NEE was $-575 \mathrm{~g} \mathrm{C} \mathrm{m}^{-2}$. This final cumulative value of $\mathrm{CO}_{2}-\mathrm{C}$ represents the amount of carbon the site accumulated from the start of the measurements in July 2009 until the end of 2011. 
Table 2. The estimated annual $\mathrm{CO}_{2}$ balances of the reed canary grass cultivation. Annual values of net ecosystem $\mathrm{CO}_{2}$ exchange (NEE), total ecosystem respiration (TER) and gross primary production (GPP) are shown in $\mathrm{g} \mathrm{C} \mathrm{m}^{-2}$. Negative values stand for uptake and positive for emission to the atmosphere. Note that 2009 is not a full year (23 July to 31 December).

\begin{tabular}{lrrr}
\hline & 2009 & 2010 & 2011 \\
\hline NEE & 56.8 & -262 & -256 \\
TER & 434 & 969 & 1043 \\
GPP & 491 & -1231 & -1299 \\
\hline
\end{tabular}

\section{Discussion}

The use of renewable energy sources such as perennial bioenergy crops has been suggested as one of the options for mitigating $\mathrm{CO}_{2}$ emissions. Cultivation of RCG, a perennial bioenergy crop, has been shown to be a promising after-use option on a cutaway peatland (a drained organic soil) in Finland (Shurpali et al., 2009, 2010). In the present study we explore further whether the benefits of RCG cultivation are limited to the organic soils only. For the purpose, we measured $\mathrm{CO}_{2}$ exchange during 3 years from the start of the crop rotation cycle on a mineral soil from the same variety of RCG crop as was used on a drained organic soil, in eastern Finland. Generating such knowledge from different soil types is useful in developing scientifically based bioenergy policies.

The studied RCG site on mineral soil was an annual sink for atmospheric $\mathrm{CO}_{2}$ with an average NEE of $-260 \mathrm{~g} \mathrm{C} \mathrm{m}^{-2}$ for 2010 and 2011 (Table 2). This net uptake rate of $\mathrm{CO}_{2}$ is higher than what has been reported previously for RCG cultivation. During a 4-year study in Finland, an annual NEE ranging from -8.7 to $-210 \mathrm{~g} \mathrm{C} \mathrm{m}^{-2}$ has been reported for a cut-away peatland with RCG cultivation in Finland (Shurpali et al., 2009) and during a 1-year study in Denmark, an annual $\mathrm{NEE}$ of $+69 \mathrm{~g} \mathrm{C} \mathrm{m}^{-2}$ was reported for an organic agricultural site (Kandel et al., 2013a). Measurements of $\mathrm{CO}_{2}$ exchange have been carried out also on other bioenergy crops. On average, annual NEE of switchgrass cultivation was $-150 \mathrm{~g} \mathrm{C} \mathrm{m}^{-2}$ during a 4-year study in USA (Skinner and Adler, 2010). Annual NEE for Miscanthus was $-420 \mathrm{~g} \mathrm{C} \mathrm{m}^{-2}$ during a 2-year study in USA (Zeri et al., 2011). Annual NEE of young hybrid poplar stand in Canada was $+37 \mathrm{~g} \mathrm{C} \mathrm{m}^{-2}$ in a 2-year study (Jassal et al., 2013). Willow stands have been studied in Sweden with an annual NEE value of $-510 \mathrm{~g} \mathrm{C} \mathrm{m}^{-2}$ in a 3-year study (Grelle et al., 2007). Compared to these studies, the annual NEE of the present study is within the range of these previously posted values from various bioenergy systems. Forests are an important source of bioenergy in the boreal region and long-term $\mathrm{CO}_{2}$ exchange studies have been carried out on Scots pine stands on mineral soils. Annual NEE of an approximately 40-yearold stand in southern Finland was $-210 \mathrm{~g} \mathrm{C} \mathrm{m}^{-2}$ during the 6-year study (Kolari et al., 2009). Average NEE of a 50-year- old stand measured during a 10-year study in eastern Finland was estimated to be $-190 \mathrm{~g} \mathrm{C} \mathrm{m}^{-2}$ (Ge et al., 2011). So, RCG in the present study has a higher capacity for carbon uptake than Scots pine on mineral soils under boreal environmental conditions.

The mineral soil site in the present study had stronger capacity to withdraw atmospheric $\mathrm{CO}_{2}$ than the same variety of RCG crop cultivated on a comparison site (a drained organic soil) in Finland (Shurpali et al., 2009). The organic site and the mineral site under investigation in this study are located approximately at the same latitude. The long-term climatic conditions between the sites are similar. Also, the variety of RCG crop planted on the study site is the same as the one cultivated on the organic soil site. Therefore, it is intuitive to compare the results from the present study with the already published results from the comparison site (Shurpali et al., 2008, 2009, 2010, 2013; Hyvönen et al., 2009; Gong et al., 2013). The main differences between the two sites lie in the soil type, nutrient status and water retention characteristics of the soil. Mineral soil site studied here is an agricultural field with soil texture of silt loam. Also the soil was rich with nutrients indicated by the low $\mathrm{C}: \mathrm{N}$ ratio. While the mineral soil site investigated here had a $\mathrm{C}: \mathrm{N}$ ratio of 14.9 , the comparison site had a $\mathrm{C}: \mathrm{N}$ ratio of 40.3 (Shurpali et al., 2008). The differences in the nutrient status of the soil types is further borne out by the fact that the mineral soil in the present study had a seasonal $\mathrm{N}_{2} \mathrm{O}$ emission from this RCG cultivation system of the order of $2.4 \mathrm{~kg} \mathrm{ha}^{-1}$ (Rannik et al., 2015), while the comparison site had negligible emissions (Hyvönen et al., 2009). Higher $\mathrm{N}_{2} \mathrm{O}$ emissions imply that the enhanced rates of soil $\mathrm{N}$ transformations in the mineral soil support active soil $\mathrm{C}$ cycling and associated high release of soil nutrients. The soil nutrients are available for the plant roots so that a vigorous plant growth can be sustained. Additionally, the soil moisture conditions during the study period at the mineral site under investigation were conducive for prolific rates of below-ground and above-ground RCG biomass growth. Based on the results presented here, it seems that the soil water movement at the mineral site was coupled with the energy load on the surface. The daily variations in soil profile moisture content (Fig. 1c) reveal that soil moisture at $30 \mathrm{~cm}$ depth also varies in phase with the surface soil moisture content at this site hinting at a coupled soil hydrological system. The soil water and heat exchange monitored in this study is thus influenced by the surface energy exchange. This is contrary to what has been reported for the comparison site. The soil moisture content at $30 \mathrm{~cm}$ depth in the comparison site was found to be rather constant and saturated throughout the growing seasons (Shurpali et al., 2009), while only the nearsurface soil layers exhibited variations in soil moisture content as affected by the radiation load on the soil surface and seasonal precipitation events. These observations hint at a decoupled hydrological system in the comparison site (Gong et al., 2013). This is further supported by the shallow rooting pattern reported in Shurpali et al., 2009) where $95 \%$ of the 
$\mathrm{RCG}$ roots were concentrated in the first $15 \mathrm{~cm}$ of the drained organic soil profile. Owing to a coupled soil hydrology, the rooting depth of RCG plants in this mineral soil, however, appears to be not constrained by hydrological limitations like the restrictions laid on the RCG root development in a cutover peatland.

The typical rotation cycle of the RCG cropping system grown for bioenergy in eastern Finland varies from 10 to 15 years. The RCG stand at the mineral site studied here was young, 0-3-year-old stand. At the comparison site the RCG stand was a matured, 4-7-year-old stand. Compared to the published yield from RCG on the comparison site, the crop yield from the study site was approximately 3.5 times higher (Shurpali et al., 2009). This difference in the aboveground biomass was visible also in the seasonal LAI with higher maximum values measured at the mineral soil site (5.4) than at the comparison site (3.5, Shurpali et al., 2013). However, the timing of the peak LAI (Fig. 2) was similar between the sites. Despite the young age of the crop on the mineral soil, RCG has a capacity to produce more biomass than the same variety of the older RCG crop on the comparison site. The average spring-harvested RCG yield reported here, $6500 \mathrm{~kg} \mathrm{DW} \mathrm{ha}^{-1}$, was not the highest yield reported for mineral soil sites in Finland. The RCG yield for mineral soils in Finland has ranged from 6400 to $7700 \mathrm{~kg} \mathrm{DW} \mathrm{ha}^{-1}$ (Pahkala and Pihala, 2000). However, we expect that the above- and below-ground biomass of the crop at our mineral soil site will further increase with the crop age. RCG on mineral soil site had higher water use efficiency $\left(12 \mathrm{~g} \mathrm{CO}_{2}\right.$ per $\mathrm{kg} \mathrm{H}_{2} \mathrm{O}$ ) when compared with published WUEs for the RCG comparison site $\left(9.1 \mathrm{~g} \mathrm{CO}_{2}\right.$ per $\left.\mathrm{kg} \mathrm{H}_{2} \mathrm{O}\right)$ or for grasslands (3.4 $\mathrm{g} \mathrm{CO}_{2}$ per $\mathrm{kg} \mathrm{H}_{2} \mathrm{O}$ ) and crops $\left(3.2 \mathrm{~g} \mathrm{CO}_{2}\right.$ per $\mathrm{kg} \mathrm{H}_{2} \mathrm{O}$ ) (Law et al., 2002; Shurpali et al., 2013). These results indicate that the RCG crop cultivated at this mineral soil site is more efficient in sequestering atmospheric $\mathrm{CO}_{2}$ per unit amount of $\mathrm{H}_{2} \mathrm{O}$ lost as ET, and thus more effective in utilizing the available resources.

As NEE is the balance between the two major opposing fluxes of GPP and TER, it is important to evaluate these processes separately. Average annual GPP $\left(-1300 \mathrm{~g} \mathrm{C} \mathrm{m}^{-2}\right)$ at the mineral soil site was in the range of what has been reported earlier for RCG cultivation on the comparison site ( $-590 \mathrm{~g} \mathrm{C} \mathrm{m}^{-2}$, Shurpali et al., 2009) and in an organic agricultural field in Denmark $\left(-1800 \mathrm{~g} \mathrm{C} \mathrm{m}^{-2}\right.$, Kandel et al., 2013a). Annual GPP of the present study is higher than what has been published earlier for switchgrass, hybrid poplar and Scots pine forests (Kolari et al., 2009; Skinner and Adler, 2010; Ge et al., 2011; Jassal et al., 2013). Annual GPP for switchgrass cultivation was $-930 \mathrm{~g} \mathrm{C} \mathrm{m}^{-2}$ in the USA (Skinner and Adler, 2010), $-540 \mathrm{~g} \mathrm{C} \mathrm{m}^{-2}$ for hybrid poplar stand in Canada (Jassal et al., 2013), $-1100 \mathrm{~g} \mathrm{C} \mathrm{m}^{-2}$ for Scots pine stand in southern Finland (Kolari et al., 2009) and $-830 \mathrm{~g} \mathrm{C} \mathrm{m}^{-2}$ for Scots pine stand in eastern Finland (Ge et al., 2011). During the summer months, GPP at our study site was limited primarily by light levels. Especially early in the summer (June-July), plants were developing rigorously. The inherent ability of the crop to sequester maximum atmospheric $\mathrm{CO}_{2}$ in this phase was seen in the high $\mathrm{GP}_{\max }$ values (Table 1). Higher photosynthesis activity at the present study on the mineral soil than at the comparison site can be explained by the higher plant productivity. Soil moisture conditions and nutrient status of the site were conductive to an optimal crop growth. Additionally, it is vital to realize that the crop water losses from the RCG crop at this site were higher than the water input to the ecosystem through precipitation events during summer periods. The $\mathrm{CO}_{2}$ uptake rates, however, do not seem to be affected by climatic stress at the mineral soil site, as the crop had the mechanism to cope with the stress by drawing the available soil moisture through capillary forces from deeper layers of the soil. This explains why the crop was limited primarily by light levels with other environmental variables having minimal role in regulating the RCG photosynthetic rates at this site.

On an annual basis, the average TER $\left(+1000 \mathrm{~g} \mathrm{C} \mathrm{m}^{-2}\right)$ for our study was within the range of what has been reported earlier for RCG cultivations at the comparison site $\left(+480 \mathrm{~g} \mathrm{C} \mathrm{m}^{-2}\right.$, Shurpali et al., 2009), in cut-away peatland Estonia $\left(+600 \mathrm{~g} \mathrm{C} \mathrm{m}^{-2}, 2\right.$-year study, Mander et al., 2012) and in the organic agricultural field in Denmark (+1900 $\mathrm{g} \mathrm{C} \mathrm{m}^{-2}$, Kandel et al., 2013a). When compared to annual TER values for switchgrass, hybrid poplar and Scots pine forest (Skinner and Adler, 2010; Jassal et al., 2013; Kolari et al., 2009), the annual TER of the present study is higher. Average annual TER for switchgrass cultivation was $+780 \mathrm{~g} \mathrm{C} \mathrm{m}^{-2}$ in the USA (Skinner and Adler, 2010), $+580 \mathrm{~g} \mathrm{C} \mathrm{m}^{-2}$ for hybrid poplar stand in Canada (Jassal et al., 2013) and $+790 \mathrm{~g} \mathrm{C} \mathrm{m}^{-2}$ for 40 -year-old Scots pine stand in southern Finland (Kolari et al., 2009). Difference in the annual respiration rates between our mineral soil site and the comparison site can be explained by differences in the biomass as higher biomass increases also autotrophic and heterotrophic respiration. TER was mainly controlled by soil temperature during the summer months at this site with plant biomass, LAI and GPP also explaining a part of the variation in TER rates. The lack of GA correlation in 2010 could be attributed to the unharvested biomass from the 2009 season. The biomass left at the site may have affected the soil respiration rates in 2010 . The base respiration $\left(R_{10}\right)$ rate $(1.75$ and $1.66 \mu \mathrm{mol} \mathrm{m}^{-2} \mathrm{~s}^{-1}$ in 2010 and 2011 , respectively) and $Q_{10}$ (2.17 and 2.35 in 2010 and 2011 , respectively) values were estimated in this study with a nonlinear regression of observed TER on soil temperature (Fig. 6). Both $R_{10}$ and $Q_{10}$ in the present study are in the range of what has been reported by other authors. Earlier papers have reported $R_{10}$ values for the comparison site ranging from 0.24 to $1.39 \mu \mathrm{mol} \mathrm{m}^{-2} \mathrm{~s}^{-1}$ (Shurpali et al., 2009) and for grassland in Canada ranging from 0.2 to $3.6 \mu \mathrm{mol} \mathrm{m}{ }^{-2} \mathrm{~s}^{-1}$ (Flanagan and Johnson, 2005). For $Q_{10}$, the earlier reported values range from 2.0 to 5.4 for the reference site (Shurpali et al., 2009) and from 1.2 to 2.7 grassland in Canada (Flanagan and Johnson, 2005). The 
$R_{10}$ was higher and $Q_{10}$ was lower for RCG on mineral soil; an opposite trend has been reported for the RCG comparison site (Shurpali et al., 2009). The soil temperatures did not explain the differences between the present study and the comparison site as the soil temperatures were similar in the topsoil during May-September in the sites (Shurpali et al., 2013). The higher base respiration rate observed in this study is reflective of the active cycling of soil $\mathrm{C}$ in this ecosystem.

The comparative analysis of the $\mathrm{CO}_{2}$ exchange from mineral and drained organic soil suggests that from a $\mathrm{CO}_{2}$ exchange perspective, the RCG cultivation on mineral soils is more environmentally friendly. The capacity of the RCG to withdraw atmospheric $\mathrm{CO}_{2}$ was even stronger on the mineral soil site than that on the organic soil site. For a complete estimation of the climatic impacts of RCG on mineral soil site, other greenhouse gas $\left(\mathrm{N}_{2} \mathrm{O}\right.$ and $\left.\mathrm{CH}_{4}\right)$ emissions during the crop production phase have to be included in addition to all energy inputs and outputs associated with the crop management. Only then can a complete life cycle assessment be done, as is needed to understand the sustainability of a bioenergy system. Such comparative analyses involving studies on different soil types are important in evaluating national bioenergy policies.

Acknowledgements. Data from the study are available for collaborative use by anyone interested. Contact N. J. Shurpali for information on data access (narasinha.shurpali@uef.fi). We thank numerous students and trainees of the University of Eastern Finland for technical help in the field and laboratory during this study. Additionally, we would like to thank M. Laasonen, P. Issakainen and other technical personnel of Natural Resources Institute Finland Maaninka station for their excellent support. This study is a part of Competitive and sustainable bioenergy production in Finnish agriculture (MINHELPI) and is funded by the Ministry of Agriculture and Forestry, Finland, and with UEF infrastructure funding and strategic funding of Agrifood Research Finland. S. E. Lind was additionally supported by the Finnish Doctoral Programme in Environmental Science and Technology (EnSTe).

Edited by: A. Ibrom

\section{References}

Arya, P.: Introduction to Micrometeorology, Academic press, Inc., San Diego, California, USA, 1988.

Aubinet, M., Grelle, A., Ibrom, A., Rannik, U., Moncrieff, J., Foken, T., Kowalski, A., Martin, P., Berbigier, P., Bernhofer, C., Clement, R., Elbers, J., Granier, A., Grunwald, T., Morgenstern, K., Pilegaard, K., Rebmann, C., Snijders, W., Valentini, R., and Vesala, T.: Estimates of the annual net carbon and water exchange of forests: The EUROFLUX methodology, Adv. Ecol. Res., 30, 113-175, 2000.

Baldocchi, D.: Assessing the eddy covariance technique for evaluating carbon dioxide exchange rates of ecosystems: past, present and future, Glob. Change Biol., 9, 479-492, 2003.
Biasi, C., Lind, S. E., Pekkarinen, N. M., Huttunen, J. T., Shurpali, N. J., Hyvönen, N. P., Repo, M. E., and Martikainen, P. J.: Direct experimental evidence for the contribution of lime to $\mathrm{CO}_{2}$ release from managed peat soil, Soil Biol. Biochem., 40, 2660-2669, 2008.

Burvall, J.: Influence of harvest time and soil type on fuel quality in reed canary grass (Phalaris arundinacea L.), Biomass Bioenerg., 12, 149-154, 1997.

Chatskikh, D. and Olesen, J. E.: Soil tillage enhanced $\mathrm{CO}_{2}$ and $\mathrm{N}_{2} \mathrm{O}$ emissions from loamy sand soil under spring barley, Soil Till. Res., 97, 5-18, 2007.

Elonen, P.: Particle-size analysis of soil, Acta Agralia Fennica, 122, 1-122, 1971.

Flanagan, L. B. and Johnson, B. G.: Interacting effects of temperature, soil moisture and plant biomass production on ecosystem respiration in a northern temperate grassland, Agr. Forest Meteorol., 130, 237-253, 2005.

Foken, T.: The energy balance closure problem: An overview, Ecol. Appl., 18, 1351-1367, 2008.

Foken, T. and Wichura, B.: Tools for quality assessment of surfacebased flux measurements, Agr. Forest Meteorol., 78, 83-105, 1996.

Foken, T., Göckede, M., Mauder, M., Mahrt, L., Amiro, B. D., and Munger, J. W.: Post-field data quality control, in: Handbook of micrometeorology. A guide for surface flux measurements, edited by: Lee, X., Massman, W. J., and Law, B. E., Kluwer Academic Publisher, Dordrecht, the Netherlands, 181-208, 2004.

Ge, Z., Kellomäki, S., Zhou, X., Wang, K., and Peltola, H.: Evaluation of carbon exchange in a boreal coniferous stand over a 10year period: An integrated analysis based on ecosystem model simulations and eddy covariance measurements, Agr. Forest Meteorol., 151, 191-203, 2011.

Gong, J., Shurpali, N. J., Kellomäki, S., Wang, K., Zhang, C., Salam, M. M. A., and Martikainen, P. J.: High sensitivity of peat moisture content to seasonal climate in a cutaway peatland cultivated with a perennial crop (Phalaris arundinaceae, L.): A modeling study, Agr. Forest Meteorol., 180, 225-235, 2013.

Grelle, A., Aronsson, P., Weslien, P., Klemedtsson, L., and Lindroth, A.: Large carbon-sink potential by Kyoto forests in Sweden - A case study on willow plantations, Tellus B, 59, 910-918, 2007.

Hyvönen, N. P., Huttunen, J. T., Shurpali, N. J., Tavi, N. M., Repo, M. E., and Martikainen, P. J.: Fluxes of nitrous oxide and methane on an abandoned peat extraction site: Effect of reed canary grass cultivation, Bioresource Technol., 100, 4723-4730, 2009.

IPCC: Carbon and Other Biogeochemical Cycles, in: Climate Change 2013: The Physical Science Basis. Contribution of Working Group I to the Fifth Assessment Report of the Intergovernmental Panel of Climate Change, edited by: Stocker, T. F., Qin, D., Plattner, G. K., Tignor, M., Allen, S. K., Boschung, J., Nauels, A., Xia, Y., Bex, V., and Midgley, P. M., Cambridge University Press, Cambridge, United Kingdom and New York, NY, USA, 2013.

IUSS Working Group WRB: World Reference Base for Soil Resources 2006, first update 2007, World Soil Resources Reports No. 103, FAO, Rome, 128 pp., 2007.

Järveoja, J., Laht, J., Maddison, M., Soosaar, K., Ostonen, I., and Mander, Ü: Mitigation of greenhouse gas emissions from an 
abandoned Baltic peat extraction area by growing reed canary grass: life-cycle assessment, Reg. Environ. Change, 13, 781-795, 2013.

Jassal, R. S., Black, T. A., Arevalo, C., Jones, H., Bhatti, J. S., and Sidders, D.: Carbon sequestration and water use of a young hybrid poplar plantation in north-central Alberta, Biomass Bioener., 56, 323-333, 2013.

Kandel, T. P., Elsgaard, L., and Laerke, P. E.: Measurement and modelling of $\mathrm{CO}_{2}$ flux from a drained fen peatland cultivated with reed canary grass and spring barley, GCB Bioenergy, 5, 548-561, 2013a.

Kandel, T. P., Gislum, R., Jorgensen, U., and Laerke, P. E.: Prediction of biogas yield and its kinetics in reed canary grass using near infrared reflectance spectroscopy and chemometrics, Bioresource Technol., 146, 282-287, 2013b.

Kasimir-Klemedtsson, A., Klemedtsson, L., Berglund, K., Martikainen, P., Silvola, J., and Oenema, O.: Greenhouse gas emissions from farmed organic soils: a review, Soil Use Manage., 13, 245-250, 1997.

Kolari, P., Kulmala, L., Pumpanen, J., Launiainen, S., Ilvesniem, H., Hari, P., and Nikinmaa, E.: $\mathrm{CO}_{2}$ exchange and component $\mathrm{CO}_{2}$ fluxes of a boreal Scots pine forest, Boreal Environ. Res., 14, 761-783, 2009.

Kormann, R. and Meixner, F. X.: An analytical footprintmodel for non-neutral stratification, Bound.-Lay. Meteorol., 99, 207-224, 2001.

Law, B., Falge, E., Gu, L., Baldocchi, D., Bakwin, P., Berbigier, P., Davis, K., Dolman, A., Falk, M., Fuentes, J., Goldstein, A., Granier, A., Grelle, A., Hollinger, D., Janssens, I., Jarvis, P., Jensen, N., Katul, G., Mahli, Y., Matteucci, G., Meyers, T., Monson, R., Munger, W., Oechel, W., Olson, R., Pilegaard, K., Paw, K., Thorgeirsson, H., Valentini, R., Verma, S., Vesala, T., Wilson, K., and Wofsy, S.: Environmental controls over carbon dioxide and water vapor exchange of terrestrial vegetation, Agr. Forest Meteorol., 113, 97-120, 2002.

Lewandowski, I., Scurlock, J., Lindvall, E., and Christou, M.: The development and current status of perennial rhizomatous grasses as energy crops in the US and Europe, Biomass Bioenerg., 25, 335-361, 2003.

Lindroth, A., Mölder, M., and Lagergren, F.: Heat storage in forest biomass improves energy balance closure, Biogeosciences, 7 , 301-313, doi:10.5194/bg-7-301-2010, 2010.

Lloyd, J. and Taylor, J.: On the Temperature-Dependence of Soil Respiration, Funct. Ecol., 8, 315-323, 1994.

Mammarella, I., Peltola, O., Nordbo, A., Järvi, L., and Rannik, Ü.: EddyUH: an advanced software package for eddy covariance flux calculation for a wide range of instrumentation and ecosystems, Atmos. Meas. Tech. Discuss., doi:10.5194/amt-2015-323, in review, 2016.

Mander, Ü, Järveoja, J., Maddison, M., Soosaar, K., Aavola, R., Ostonen, I., and Salm, J.: Reed canary grass cultivation mitigates greenhouse gas emissions from abandoned peat extraction areas, GCB Bioenergy, 4, 462-474, 2012.

Mauder, M., Cuntz, M., Druee, C., Graf, A., Rebmann, C., Schmid, H. P., Schmidt, M., and Steinbrecher, R.: A strategy for quality and uncertainty assessment of long-term eddy-covariance measurements, Agr. Forest Meteorol., 169, 122-135, 2013.
Meyers, T. and Hollinger, S.: An assessment of storage terms in the surface energy balance of maize and soybean, Agr. Forest Meteorol., 125, 105-115, 2004.

Moncrieff, J. B., Massheder, J. M., deBruin, H., Elbers, J., Friborg, T., Heusinkveld, B., Kabat, P., Scott, S., Soegaard, H., and Verhoef, A.: A system to measure surface fluxes of momentum, sensible heat, water vapour and carbon dioxide, J. Hydrol., 189, 589-611, 1997.

Nakai, T., van der Molen, M. K., Gash, J. H. C., and Kodama, Y.: Correction of sonic anemometer angle of attack errors, Agr. Forest Meteorol., 136, 19-30, 2006.

Pahkala, K. and Pihala, M.: Different plant parts as raw material for fuel and pulp production, Ind. Crop. Prod., 11, 119-128, 2000.

Partala, A., Mela, T., Esala, M., and Ketoja, E.: Plant recovery of $\mathrm{N}-15$-labelled nitrogen applied to reed canary grass grown for biomass, Nutr. Cycl. Agroecosys., 61, 273-281, 2001.

Pasila, A. and Kymäläinen, H. R.: Frost processed reed canary grass in oil spill absorption, Molecular Crystals and Liquid Crystals Science and Technology, Section A. Molecular Crystals and Liquid Crystals, 353, 1-10, 2000.

Pirinen, P., Simola, H., Aalto, J., Kaukoranta, J., Karlsson, P., and Ruuhela, R.: Climatological statistics in Finland 1981-2010, Reports 2012:1, Finnish Meteorological Institute, Helsinki, Finland, 83 pp., 2012.

Powlson, D. S., Riche, A. B., and Shield, I.: Biofuels and other approaches for decreasing fossil fuel emissions from agriculture, Ann. Appl. Biol., 146, 193-201, 2005.

Rannik, Ü. and Vesala, T.: Autoregressive filtering versus linear detrending in estimation of fluxes by the eddy covariance method, Bound.-Lay. Meteorol., 91, 259-280, 1999.

Rannik, Ü., Haapanala, S., Shurpali, N. J., Mammarella, I., Lind, S., Hyvönen, N., Peltola, O., Zahniser, M., Martikainen, P. J., and Vesala, T.: Intercomparison of fast response commercial gas analysers for nitrous oxide flux measurements under field conditions, Biogeosciences, 12, 415-432, doi:10.5194/bg-12-4152015, 2015.

Reichstein, M., Falge, E., Baldocchi, D., Papale, D., Aubinet, M., Berbigier, P., Bernhofer, C., Buchmann, N., Gilmanov, T., Granier, A., Grunwald, T., Havrankova, K., Ilvesniemi, H., Janous, D., Knohl, A., Laurila, T., Lohila, A., Loustau, D., Matteucci, G., Meyers, T., Miglietta, F., Ourcival, J., Pumpanen, J., Rambal, S., Rotenberg, E., Sanz, M., Tenhunen, J., Seufert, G., Vaccari, F., Vesala, T., Yakir, D., and Valentini, R.: On the separation of net ecosystem exchange into assimilation and ecosystem respiration: review and improved algorithm, Glob. Change Biol., 11, 1424-1439, 2005.

Schotanus, P., Nieuwstadt, F., and Debruin, H.: TemperatureMeasurement with a Sonic Anemometer and its Application to Heat and Moisture Fluxes, Bound.-Lay. Meteorol., 26, 81-93, 1983.

Shurpali, N. J., Hyvönen, N. P., Huttunen, J. T., Biasi, C., Nykänen, H., Pekkarinen, N., and Martikainen, P. J.: Bare soil and reed canary grass ecosystem respiration in peat extraction sites in Eastern Finland, Tellus B, 60, 200-209, 2008.

Shurpali, N. J., Hyvonen, N. P., Huttunen, J. T., Clement, R. J., Reichstein, M., Nykanen, H., Biasi, C., and Martikainen, P. J.: Cultivation of a perennial grass for bioenergy on a boreal organic soil - carbon sink or source?, GCB Bioenergy, 1, 35-50, 2009. 
Shurpali, N. J., Strandman, H., Kilpeläinen, A., Huttunen, J., Hyvönen, N., Biasi, C., Kellomäki, S., and Martikainen, P. J.: Atmospheric impact of bioenergy based on perennial crop (reed canary grass, Phalaris arundinaceae, L.) cultivation on a drained boreal organic soil, GCB Bioenergy, 2, 130-138, 2010.

Shurpali, N. J., Biasi, C., Jokinen, S., Hyvönen, N., and Martikainen, P. J.: Linking water vapor and $\mathrm{CO}_{2}$ exchange from a perennial bioenergy crop on a drained organic soil in eastern Finland, Agr. Forest Meteorol., 168, 47-58, 2013.

Skinner, R. H. and Adler, P. R.: Carbon dioxide and water fluxes from switchgrass managed for bioenergy production, Agr. Ecosyst. Environ., 138, 257-264, 2010.

Statistics Finland: Greenhouse gas emissions in Finland 19902012, National Inventory Report under the UNFCCC and the Kyoto Protocol, 471 pp., 2014.

Thornley, J. H. M. and Johnson, I. R.: Plant and Crop Modeling: A Mathematical Approach to Plant and Crop Physiology, Clarendon, Oxford, England, 1990.

Vickers, D. and Mahrt, L.: Quality Control and Flux Sampling Problems for Tower and Aircraft Data, J. Atmos. Ocean. Tech., 14, 512-526, 1997.
Vuorinen, J. and Mäkitie, O.: The method of soil testing in use in Finland, Agrogeological Publications, 63, 1-44, 1955.

Wilson, D., Alm, J., Riutta, T., Laine, J., and Byrne, K. A.: A high resolution green area index for modelling the seasonal dynamics of $\mathrm{CO}_{2}$ exchange in peatland vascular plant communities, Plant Ecol., 190, 37-51, 2007.

Wilson, K., Goldstein, A., Falge, E., Aubinet, M., Baldocchi, D., Berbigier, P., Bernhofer, C., Ceulemans, R., Dolman, H., Field, C., Grelle, A., Ibrom, A., Law, B. E., Kowalski, A., Meyers, T., Moncrieff, J., Monson, R., Oechel, W., Tenhunen, J., Valentini, R., and Verma, S.: Energy balance closure at FLUXNET sites, Agr. Forest Meteorol., 113, 223-243, 2002.

Zeri, M., Anderson-Teixeira, K., Hickman, G., Masters, M., DeLucia, E., and Bernacchi, C. J.: Carbon exchange by establishing biofuel crops in Central Illinois, Agr. Ecosyst. Environ., 144, 319-329, 2011. 